\title{
PATRONAGE OF ISLAMIC AND CONVENTIONAL BANKS: THE CASE OF SYRIA
}

\author{
Khaled Nour Aldeen $^{1 *}$, Syed Alamdar Ali Shah ${ }^{2}$, Sri Herianingrum ${ }^{3}$ \\ ${ }^{1}$ Department of Banking and Insurance, Faculty of Economics, Damascus University \\ Fawzi Al Laham Street, Damascus, Syria \\ khaled.knd@hotmail.com \\ ${ }^{2}$ Department of Business Administration, Faculty of Economics and Commerce, \\ Superior University \\ $17 \mathrm{~km}$ Raiwind Rd, Kot Araian, Lahore, Punjab, Pakistan \\ alamdar2000pk@yahoo.com \\ ${ }^{3}$ Department of Islamic Economics, Faculty of Economics, Universitas Airlangga \\ Jalan Airlangga No.4, Airlangga, Gubeng, Surabaya, Indonesia \\ sri.herianingrum@feb.unair.ac.id
}

\begin{abstract}
The aim of this study is to understand perception of conventional banks' customers towards Islamic banking by examining their level of awareness about Islamic banking. The qualitative approach was used in the form of semi-structured interviews under the phenomenological approach in Damascus city. The main findings of this research are customers lack awareness of Islamic banking operations. Furthermore, Islamic banks' stuff play a crucial rule to enhance awareness and willingness towards their services. This study revealed that an informative advertising campaign is highly recommended to raise the awareness level among Syrians towards Islamic banking. Moreover, Islamic banks should be more selective especially when they recruit customer service operation staff. This research is a pioneering attempt towards Islamic banking issues in the case of Syria from a customer perspective. It contributes to the Syrian perceptions towards Islamic banking literature.
\end{abstract}

Keywords: Patronage; Islamic banks; Conventional banks; Syria. 


\begin{abstract}
Abstrak
Tujuan dari penelitian ini adalah untuk memahami persepsi nasabah bank konvensional terhadap perbankan syariah dengan menguji tingkat kesadaran mereka tentang perbankan syariah. Pendekatan kualitatif digunakan dalam bentuk wawancara semi-terstruktur di bawah pendekatan fenomenologis. Temuan utama dari penelitian ini adalah nasabah kurang memiliki kesadaran akan sistem operasional perbankan syariah. Selain itu, barang-barang bank syariah memainkan aturan penting untuk meningkatkan kesadaran dan kemauan terhadap layanan mereka. Studi ini mengungkapkan bahwa kampanye iklan informatif sangat dianjurkan untuk meningkatkan tingkat kesadaran masyarakat Suriah terhadap sistem perbankan syariah. Selain itu, bank syariah harus lebih selektif terutama ketika mereka merekrut staf operasional layanan nasabah. Penelitian ini merupakan upaya perintis terhadap masalah perbankan syariah dalam kasus Suriah dari perspektif nasabah. Hal ini berkontribusi pada persepsi Suriah terhadap literatur perbankan syariah.
\end{abstract}

Kata kunci: Bank Syariah; Bank Konvensional, Suriah. 


\section{INTRODUCTION}

Syrian banks have been suffering from crisis since 2011 which has affected their profits, work, and results. It has been through fluctuated history, extending from the Ottoman occupation. Over the period of time mechanisms of management and other aspects have changed drastically (Al-Jafari and Alchami, 2014). This long period witnessed transition from dominance of foreign banks passing through the banking business in the pre-independence period to the stage of the presence of private national and Arab banks in the post-independence phase (Mohamad, 2015). After a long period of absence of private banking and after the conviction of the inability of public banks to meet the financial needs of the state, institutions and citizens, legislative decree in 2001 allowed private banks to operate in Syria, followed by another announcement allowing Islamic banks to start up in 2005 (Central bank of Syria, 2019).

Islamic banking indicates to banking system which works according to Islamic roles (sharia). Sharia prohibits charging any extra money for money that is borrowed, rather it builds on profit and loss sharing instead (Farikhah and Rani 2019); (Kamarulzaman and Madun, 2013). Islamic finance industry has achieved significant progress at global level (Abduh, and Azmi Omar, 2012). It is growing rapidly in both Muslim and non-Muslim majority countries. Furthermore, it has become a vital part of universal banking system (Muhammad and Abida, 2017)

Egypt's Mit Gamar saving bank was the millstone initiative step towards Islamic banking which was based on profit and loss sharing (Cengiz, Erdener, and El-Bdour, 1990). Kpodar (2016) cited in (Cham, 2018) investigating economic growth associated with Islamic banking covering 52 countries found that Islamic banking is highly correspond with economic growth considering the other determinants of growth. Significant growth of Islamic banking systems across Asia, Africa and the Middle East has initiated an attractive alternative to the conventional banking products. Hence, Islamic banking is achieving rapid growth in countries wherein it was totally absent in the past. 
While Islamic banking industry has become popular in both Muslim and nonMuslim countries, it has not achieved significant acceptance in Syria. Currently, there are three full-fledged Islamic banks operating in Syria namely Albarakah Bank, Cham Bank and Syrian International Islamic Bank. Establishment of a fullfledged Islamic retail bank in the country would cater for the demand of businessmen, Muslim and non-Muslim alike, small and medium enterprises (SMEs). It will also help to meet Sustainable Development Goals and provide for better financial inclusion (Rassool, 2018). Islamic banking can no longer be regarded as a system to fulfill religious duties. It is competitive with the conventional banking system in attracting more clients and retain them. Inevitably, Islamic banks need to understand the perceptions of their customers towards their business operations particularly their quality of service rendered to increase customer satisfaction and subsequently their loyalty (Dusuki and Abdullah, 2007).

The literature on Islamic banking lines that many researchers have endeavored to examine awareness level among people in different countries (Butt et al, 2018) in the case of Pakistan, Singapour (Gerrard and Cunningham, 1997), Malaysia (Hamid and Nordin, 2001) and India (Islam, and Rahman, 2017) but to the best of the author knowledge there is no previous study addressed the case of Syria.

A notable challenge in front of the Islamic banking industry in Syria pertains to the lack of qualified Sharia scholars well versed in Islamic banking and finance in the country. This may restrain the promotion and acceptance of services and products offered by Islamic banks in the country. This study focuses conventional banking customers who have started utilizing Islamic banking services. Consequently, it works on the perception of Muslims towards Islamic banking services and products. It is vital to research the perception of conventional banks' customers in Syria about Islamic banks which is particularly useful because no previous study has included Islamic banks industry in Syria.

Islamic banking is a system governed by sharia law. The source of these laws is Quran and Sunnah of prophet Mohammad SWT. The fundamental difference between the two systems i.e., conventional and Islamic banking is the prohibition 
of Riba, according to Bouslama and Lahrichi (2017) Riba refers to the extra amount of money that the lender obligates the borrower to pay on the top of the principal amount. Return of money on money (Rassool, 2018). Moreover, according to Quran and Sunnah Islam prohibits some activities such as Mayser, Gharar, and Haram which are respectively gambling, speculation and venturing in businesses such as Alcohol and Pork trade which are illegal in Quran.

According to Atmeh and Ramadan (2012) Mudarabah is an Islamic banking contract where one party offers the financing of the project and the other part manages its business. While the money provider provides all the capital requirements, all the profits gained from investment is distributed according to the percentage in the contract. Musharkah is contract based on profit and loss sharing. Both partners contribute capital and agree share the loss in proportion to the capital contribution. The profits are shared according to the agreed percentage. Murabaha is an agreement where a commodity is sold usually at a price including a profit margin. In Ijarah arrangement, rental fees are paid to the asset owner.

Sukuk refers to reward future cash flows based on the underlying asset. It maybe for existing asset or asset will be exchanged in future. Sukuk to a large extent are similar to the bonds but the vital difference is that the bonds are based on interest and Sukuk are asset-backed (Nik Abdul Ghani, 2018). Refer to Zakat is third of fifth pillars of Islam, briefly it is distributing a specific proportion of people's wealth to the people in need (Djaghballou et al., 2018).

Despite the fact that Islamic banking has grown rapidly across the world, it has grabbed a little scholarly attention in Syrian context. The amount of information in Islamic banking grows continuously in Muslim majority countries (Sulaiman et al., 2016). To the best of the authors' knowledge, there is no study conducted in Islamic banking awareness regards in the case of Syria. Erol and El-Bdour (1989) cited in Gerrard and Cunningham (1997) stated that religious orientation did not seem to be a primary role in bank choice whether it was Islamic or conventional.

Despite huge amount of information in Islamic banking relatively its awareness is among masses is low (Asma et al., 2011). Religious beliefs influence to choose the bank described by Omar (1992) in the survey of Muslims in the case 
of UK when Islamic banking product offered by Islamic windows in conventional banks.

Religious belief one of the most important standard that affect banks selection (Al-Sultan, 1999) in case of Kuwaitis' society, which is conflict with (Erol and ElBdour, 1989) findings, which is shows that the religion is the main aspect that influence the bank selection, that could be attributed to the country population whether it is Muslim majority or not. Jasim and Al-Saleh (2009) found that Muslims in Bahrain who area utilizing Islamic banking services are more aware comparing to Muslims who are patronizing conventional banks services for their transactions. In a study of Malaysian commercial customers Hamid and Nordin (2001) found high level of awareness of Islamic banking but poor self-reported knowledge of Islamic products mechanism. Additionally, poor comprehension of the differences between Islamic banks and its counterparts.

Islamic banking has deviated from their main focus of Islamic economy and Islamic banks should be aligned with social ends of financial transactions instead of focusing only on the contract mechanism (Asutay, 2007). On the other hand, Islamic banking has become an indispensable element of the whole banking system in many countries either Muslims majority or minority countries (Rammal and Zurbruegg, 2006). Besides, Islamic banking information gap is predicted to decline in the years to come, as a huge number of Islamic banks are delivering the Islamic finance products. Islamic banking is appealing internationally and implemented rather than philosophized theory (Islam and Rahman, 2017).

Islamic banks invest in Shariah compliant activities. Such as the business indirectly or directly involved in gambling, pornography and alcohol drinks or any other businesses that might hurt the social welfare are also prohibited (Kamarulzaman and Madun, 2013). Considering the abovementioned, Muslims have no desire to apply conventional banking services which involves non shariah compliant activities in their operations (Gerrard and Cunningham, 1997, Rammal and Zurbruegg, 2006; Islam and Rahman, 2017). The profit and loss sharing model forces parties to work together as partner rather than creditor and debtor relationship (Butt et al., 2018). 
To harmonize the subject matter, Islamic banks have started serving markets by developing Sharia-compliant banking products which are to some extent fulfilling the requirements of both Muslim and non-Muslims requirements (Rammal and Zurbruegg, 2006; Islam and Rahman, 2017). A variety of shariacompliant products are offered by Islamic banks. Most commonly used products include Murabaha (i.e. cost-plus financing), Mudaraba (i.e. finance trusteeship), Musharaka (i.e. equity partnership), Ijara (i.e. hire purchase contract), and Bai Salam (i.e. forward sale) (Islam and Rahman, 2017). However, Islamic banking lacks in Islamic finance products as a result of strict sharia roles. Islamic scholars try to find creative Islamic finance products by combining and modifying such contracts in such a way that it does not conflict with sharia principles. Facilitate their business matters subsequently (Al-Salem, 2009).

To assure that Islamic banking awareness assessed in countries wherein it has not been studied recently this study seeks a deeper understanding of Islamic banking perceptions among customers who patronize conventional banks in Syria. Many researchers have endeavored to examine awareness level among people in different countries (Islam and Rahman, 2017); (Gerrard and Cunningham, 1997); (Rammal and Zurbruegg, 2006), but there is starvation of such a researches in Syrian context. Therefore, this research is an effort to assess Syrian awareness of Islamic banking products. In the years yet to come, Islamic finance institutions want to expand their market portion in Syria they can have a cursory idea about the customers' perception, subsequently, it assists the Islamic finance institutions which operating currently in Syria to adjust their strategies accordingly.

\section{RESEARCH METHODS}

The main purpose of applying qualitative research methodology for this study is to generate inclusive information to examine the perception of conventional bank customers about Islamic banks in Syria. Consequently, end up with a comprehensive information to achieve the research main goals. Brief answers to structured questions will not be able to give the required in-depth to assess the issue in hand adequately (Weischedel et al., 2005) in (Echchabi and Abd. Aziz, 2014). 
We selected a total of 10 interviewees, 7 male and 3 female, who had bank accounts in conventional banks, aged 20 and above, with 150000 S.P monthly income, Damascus city resident, at least 2 years banking experience and Welleducated individuals who have the ability to understand and respond questions in connection with the specific issues of banks operations. Two among them were multiple bank users and 7 were single banks users. Only one interviewee was working as a human resources manager in Syrian Islamic bank, we assumed interviewing such a person will reflect the education level of the Islamic banks' employees. (Polit, Beck and Hungler, 2001) cited in (Echchabi and Abd. Aziz, 2014) advise that 10 interviewees is enough to allow an in-depth exploration in phenomenological researches. And the number of the respondents is considered enough, as has been used in previous studies (Echchabi and Abd. Aziz, 2014; Koenigstorfer and Klein, 2010).

To reach the interviewees' experience, we conducted in-depth interviews of participants separately, in particular, semi-structured interview, using a recorder. Approximately 30 minutes for each. Before playing the record, the interviewees were given a guarantee that their identities will not appear in any publication.

The following are the main directed question to interviewees:

- Have you ever heard of Islamic banks?

- What were the main reasons that push you away from using Islamic banks?

- Do you have any plan to move to Islamic banking in the future?

- Do you know whether Islamic bank differ from its counterparts?

All the ten interviews' record reviewed several times before transcribing. Thus, a phenomenological analysis approach was applied, to achieve a comprehensive understanding of participant opinion about Islamic banking.

The aspiration of the qualitative research was to promote a better understanding of conventional bank customer's perspective as well as their perception towards Islamic banking and its products. The analysis of transcription showed the emergence of a number of issues such as customer service, religion, customer awareness, and Islamic banks' products. 


\section{RESULTS AND DISCUSSION}

\section{Awareness Level Among Conventional Banks' Customers About Islamic Banking Operations}

The main concern of this study is to examine the awareness level about Islamic banking products among customers who are patronizing conventional banking about Islamic banks products. The interviews show evidence that almost none of the customers who are using conventional banking are aware of how do Islamic banks operate, interviewee $\mathrm{G}$ noted:

"Islamic banks in Syria using the word "Islamic" only to attract Muslims customers, the evidence is getting finance from the conventional bank is easier than the Islamic one."

The lack of awareness is also obvious from the interviewee B words:

"I don't really emphasis on this issue, as long as both can offer the services safely, nothing else matter."

On the other hand, interviewee $\mathrm{C}$ associates his awareness to the services' price comparing to the conventional banks:

"For me, I believe that Islamic banks in Syria apply for sharia roles, but how can I apply Islamic banking if its counterparts offer the same services more efficiently, With applicable terms and conditions"

In the same context, the interviewee E noted that:

"I learned that Riba is prohibited in Islam, but what proves to me that Islamic banks in Syria are sharia-compliant. When I bought my car, I have been forced by the car company to get the credit through Islamic bank, what I realized nothing different from its counterparts."

Additionally, interviewee $\mathrm{H}$ noted the following:

"Islamic and conventional banks are totally the same, the Islamic one changes the Billboard and quotes that we are following Islamic 
roles, how come it is Islamic and its almost same with interest rate offered by the conventional banks, in some cases its higher."

The abovementioned statement by interviewee $\mathrm{H}$ goes alongside with the findings of (Dusuki and Abozaid, 2007) claiming that Islamic banking used many of interestlike instruments.

Finally, the interviewee $\mathrm{C}$ was concerned about the benchmark which supports the argument of (Echchabi and Abd. Aziz, 2014):

"In fact, the benchmark of the profit rate to the interest rate is my main concern, Islamic banks do not need to look after the conventional; they have to set their own basis, to move away from the conventional banking practices and prove to me as customer that they differ from its counterparts, in my own perception, at the time they eliminate the interest rate, they will appear in astonishingly in the market."

Overall, the interviewees show a weak awareness level towards Islamic banking operations. The interviewees were mainly concerned about how can you prove that Islamic banks apply sharia-compliant products, and mimicking the Islamic banks' operations, with obvious doubt about the Islamic banks' honesty and this result supports (Islam and Rahman, 2017) and (Echchabi and Abd. Aziz, 2014) findings.

\section{Islamic Banks Role In Abovementioned Lacks Awareness Towards Islamic Banking Products}

As a result, from interviewing one of the HR members (interviewee J) in Syrian International Islamic Bank, he declared:

"We do not consider neither candidate previous experience nor educational background the most when we recruit someone to work in customer service operations. Our consideration is focused on the military status rather than his educational background or previous work experience " 
"I can admit that our current marketing policy does not focus on attracting more customers or conducting events to increase awareness. Our management attributes that to the conflict in the country, they declared: "our goal is to maintain our name, regardless of the losses that we are going to endure", because they believe one day in Syria everything will resolve and the bank will be so busy during the coming reconstruction period."

In the same context, interviewee A declared:

"Islamic banking industry is relatively new, but neither the government nor the Islamic banks operating in our country are trying to educate us about its basics."

Form the interviewee above, it is evident that Islamic banks refrain from hiring qualified people who have not finished their military service, because the bank will train the candidate and it is considered costly from the bank standpoint to leave the position after a long training period. The training usually focuses on the bank working mechanism rather than Islamic products and how they differ from the conventional ones (according to my internship in the bank). Thus, this increases the unawareness level among Syrians although it should be the other way round.

The customer service employees must be able to provide further explanation or answer for any question directed to them from a customer in the bank operations regards, since the way Islamic banks conduct their business may motivate the clients to choose financial products based on Shariah principles (Jasim and AlSaleh, 2009). Furthermore, Islamic banks don't conduct any informative marketing campaign, which is a must to be conducted by the Islamic banks to increase their market shares, the government should support this campaigns if they appreciate the subsequent from evolving Islamic banking system efficiently.

\section{What factors influence Muslims to utilize conventional banking services instead of Islamicones}

After examining the awareness level of each interviewee about Islamic banking in general, we explore the main factors that influence their decisions to utilize 
conventional bank services. When it comes to the bank services' cost, the interviewee $\mathrm{C}$ mentioned:

"I have two bank accounts in both types of banks. What prompted me to utilize conventional bank instead of the Islamic one is because the additional charge applied by Islamic banks in each transaction I did there is an extra charge for each transaction, is it the cost of being Muslim?"

It shows some of the Islamic bank customers claiming that there are small added fees for each transaction. What we want to show from the abovementioned response of the customers that there is a perception that Islamic banks services are costlier compared to its counterparts.

While the interviewee H noted:

"I have no problem to utilize Islamic banking services, but for me the availability of a good network of conventional banks branches facilitates my daily banking transactions."

In the same context, interviewee E pronounced in the same context:

"I have been in Islamic banks branches and I realized that conventional branches are more attractive in term of branch design, and the way I am treated by the customer services is incomparable."

Interviewee $\mathrm{H}$ has been specific by elaborating the main obstacle for daily banking transactions, is the availability of manageable conventional banks network. On the other hand, interviewee $\mathrm{E}$ focused on the convenience associated with the services, branches are well-organized and the customer services care, like treating customer with courtesy and respect (Sulaiman et al., 2016) and (Cengiz, et al., 1990). They found that conventional banks care more about their customers, and customers are more appreciated.

\section{CONCLUSION}

The main purpose of this study is to understand perception of conventional banks' customers towards Islamic banking by examining their level of awareness about 
Islamic banking. Moreover, understanding the main factors that influence their discussions to patronize conventional banks services. It will consequently give information to Islamic banks operating in Syria to enlarge their potential clients.

The customers who are utilizing conventional banks services lacking awareness of Islamic banking working mechanism. In case of Syria an intensive informative marketing campaign is required, to increase the locals' awareness about Islamic banking. Whoever does it operate, should pay extra attention on how do Islamic banks differ from its counterparts. It is insistent for these banks to understand customer perceptions in their communities in order to improve suitable strategies to raise their client base.

On the other hand, Islamic banks playing a crucial role in the society's awareness level. Availability of highly qualified customer services team will help the subject matter positively. Islamic banks must be more selective and amend their selection criteria. Islamic banks' staff will have to acquire many new techniques and comprehend new procedures to operate Islamic banking system. This will distinctly be a time-consuming process which would be aroused by two other factors which are the big number of employees to be re-trained. Moreover, the supplementary staff that needs to be enrolled

Admittedly, those three Islamic banks which are currently operating in the Syrian market should consider that they are competing with 18 conventional banks. Subsequently, the well-distributed branches network should be considered as well as attractive infrastructure to upsize the potential clients. All in all, friendly personnel, transaction fees, competent and knowledgeable personnel, convenience, inspiring confidence in customers, professional advice, Islamic working environment, bank's branches network, transaction fees, social responsibility, products' price, quality of service, credibility, advertisement, prestige, reception, location, size of the bank, advertisement, reception, are all recommended to be improved in Islamic banking sector, consequently convincing the customer to utilize Islamic banking service.

This paper focuses on customers who are patronizing conventional banks. Further study should consider Muslims and non-Muslims awareness and 
willingness towards Islamic banking in Syria because its products can be marketed to Muslims and non-Muslims alike.

\section{REFERENCES}

Al-Ajmi, j. and Al-Saleh, H.H.A.N. 2009. Clients of conventional and Islamic banks in Bahrain. International Journal of Social Economics, Vol. 36 No. 11: 1086-1112.

Al-Jafari, M. K., and Alchami, M. 2014. Determinants of bank profitability: Evidence from Syria. Journal of Applied Finance \& Banking, Vol 4 No.1: 1745 .

Al-Salem, F. H. 2009. Islamic financial product innovation. International Journal of Islamic and Middle Eastern Finance and Management, Vol. 2 No.3: 187200.

Al-Sultan, W. 1999. Financial characteristics of interest-free banks and conventional banks. PhD dissertation, University of Wollongong, Wollongong.

Abduh, M., and Azmi Omar, M. 2012. Islamic banking and economic growth: The Indonesian experience. International Journal of Islamic and Middle Eastern Finance and Management, Vol5 No. 1, 35-47.

Asma, R. I.K. N. M., Naziman, S. S. J., Asari, F. F. A. H., Muhammad, N., Sabri, S. M., and Jusoff, K. 2011. Religious value as the main influencing factor to customers patronizing Islamic bank. World Applied Sciences Journal, Vol.12: 8-13.

Asutay, M. 2007. Conceptualisation of the second best solution in overcoming the social failur of Islamic finance: examining the overpowering of homoislamicus by homoeconomicus. IIUM Journal of Economics and Management, Vol. 15: 167-95.

Atmeh, M. A., and H. Ramadan, A. 2012. A critique on accounting for the mudarabah contract. Journal of Islamic Accounting and Business Research, Vol. 3 No.1, 7-19.

Bouslama, G. and Lahrichi, Y. 2017. Research in International Business and Finance Uncertainty and risk management from Islamic perspective. Research in International Business and Finance, Vol.39: 718-726.

Butt, I., Ahmad, N., Naveed, A. and Ahmed, Z. 2018. Determinants of low adoption of islamic banking in pakistan. Journal of Islamic Marketing, Vol. 9 No. 3: 655-672. 
Cham, T. 2018. Determinants of Islamic banking growth: an empirical analysis. International Journal of Islamic and Middle Eastern Finance and Management, Vol. 11 No. 1: 18-39.

Cengiz, E., Erdener, K. and El-Bdour, R. 1990. Conventional and Islamic Banks: Patronage Behaviour of Jordanian Customers. International Journal of Bank Marketing, Vol. 8 No.4 : 25-35.

Central bank of Syria 2019. Legislations and Regulations, available at http://www.cb.gov.sy/en/legislations-laws/all (accessed 21 January 2019).

Djaghballou, C.E., Djaghballou, M., Larbani, M. and Mohamad, A. 2018. Efficiency and productivity performance of zakat funds in Algeria. International Journal of Islamic and Middle Eastern Finance and Management, Vol11 No.3: 474-494.

Dusuki, A.W. and Abdullah, N. I. 2007. Why do Malaysian customers patronise Islamic banks?. International Journal of Bank Marketing, Vol.25 No.3: 142160.

Echchabi, A. and Abd. Aziz, H. 2014. Shari'ah issues in Islamic banking: a qualitative survey in Malaysia. Qualitative Research in Financial Markets, 6 (2):198-210.

Farikhah, K. and Rani, L. N 2019. Determinants Of Profitability Of Sharia Regional Development Banks In Indonesia 2014-2017. Al-Uqud: Journal of Islamic Economics, Vol. 3 No 1, 1-17.

Gerrard, P. and Cunningham, B. 1997. Islamic banking: a study in Singapore. International Journal of Bank Marketing, Vol15 No.6:204-216.

Hamid, A.H. and Nordin, N.Z. 2001. A Study on Islamic Banking Education and Strategy for the new Millennium - Malaysian Experience. International Journal of Islamic FinancialService. Vol.2 No.4: 3-11.

Islam, J.U. and Rahman, Z. 2017. Awareness and willingness towards Islamic banking among Muslims: An Indian perspective. International Journal of Islamic and Middle Eastern Finance and mangement, Vol.10 No.1: 92-101.

Kamarulzaman, Y. and Madun, A. 2013. Marketing Islamic banking products: Malaysian perspective. Business Strategy Series, Vol.14 No.3: 60-66.

Koenigstorfer, J. and Klein, A.G. 2010. Examining the use of nutrition labelling with photoelicitation. Qualitative Market Research: An International Journal, Vol13 No.4: 389-413. 
Merriam, S.B. 2009. Qualitative Research: A Guide to Design and Implementation. Jossey Bass, San Francisco: CA.

Mohamad, M. j. 2015. use the financial analysis tools to evaluate the performance of islamic vs conventional banks in syria (2007-2014). Unpublished Master thesis, Damascus university, Damascus.

Muhammad,T.M., Abida Z., 2017. How Islamic is Islamic banking in Pakistan?, International Journal of Islamic and Middle Eastern Finance and Management, Vol. 10 No.4, pp.470-483

Nik Abdul Ghani, N.A.R. 2018. Beneficial ownership in sukuk ijarah: a shari'ah appraisal. International Journal of Islamic and Middle Eastern Finance and Management, Vol.11 No.1: 2-17.

Omer, H. 1992. The implication of Islamic beliefs and practice on Islamic financial institutions in the UK. PhD dissertation, Loughborough University, Loughborough.

Rammal, H. and Zurbruegg, R. 2006. Awareness of Islamic banking products among Muslims: thecase of Australia. Journal of Financial Services Marketing, Vol.12: 65-74.

Rassool, N.H. 2018. Towards establishing an Islamic retail bank in a Muslimminority country: Prospects and challenges in Mauritius. ISRA International Journal of Islamic Finance, Vol.10 No.1 :78-84.

Slam, J.U. and Rahman, Z. 2017. Awareness and willingness towards Islamic banking among Muslims: An Indian perspective. International Journal of Islamic and Middle Eastern Finance and Management, Vol10 No.1: 92-101.

Sulaiman .L., Mustafa, O. M., Rusni. B. T., Umar. A. O. 2016.The feasibilityof adopting Islamic Banking system under the existing laws in Uganda. International Journalof Islamic and Middle Eastern Finance and Management, Vol.9 No.3: 417-434.

Tijani, B., Fifield, S.G.M. and Power, D.M. 2009. The appraisal of equity investments by Nigerian investors. Qualitative Research in Financial Markets, Vol.1 No.1: 6-26. 